\title{
USE OF ZIRCONIUM PHOSPHATE SYSTEM AS A PHOTOCATALYST: PHOTOBLEACHING OF TOLONIUM CHLORIDE
}

\author{
O. P. Panwar ${ }^{1}$, Anil Kumar ${ }^{1}$, Rameshwar Ameta ${ }^{1}$, Suresh C. Ameta ${ }^{2}$ \\ ${ }^{1}$ Photochemistry and Solar Energy Laboratory, Department of Chemistry, M. L. Sukhadia University, \\ Udaipur (Rajasthan) 313001 India \\ ${ }^{2}$ Govt. Meera Girls College, Udaipur (Rajasthan) 313001 India \\ ameta_sc@yahoo.com// anilchohadia@yahoo.co.in
}

\begin{abstract}
Water pollution due to effluents from dyes and printing industries poses a serious problem for aquatic life. Photocatalysis has attracted the attention of chemists all over the world because it is an efficient and ecofriendly process to combat the problem of water pollution. Photocatalytic bleaching of tolonium chloride on zirconium phosphate was carried out in presence of light. The progress of the reaction was monitored spectrophotometrically, and it follows pseudo first order kinetics. The effect of variation of different parameters, like concentration of tolonium chloride, $\mathrm{pH}$, amount of semiconductor and light intensity on the rate of bleaching, was also studied. A tentative mechanism for the photocatalytic bleaching of tolonium chloride has been proposed.
\end{abstract}

Key words: wastewater treatment; photocatalytic bleaching; tolonium chloride; zirconium phosphate; semiconductor

\section{КОРИСТЕЊЕ НА ЦИРКОНИУМФОСФАТ КАКО ФОТОКАТАЛИЗАТОР: БЕЛЕЊЕ НА ТОЛОНИУМХЛОРИД}

\begin{abstract}
Загадувањето на водите со индустриски бои претставува сериозна закана за водниот животински и растителен свет. За решавање на проблемите, кои се однесуваат на загадување на водите, фотокатализата привлекува внимание на хемичарите од целиот свет, како еколошки и ефикасен процес. Во овој труд е прикажана примена на процесот на фотокаталитичко белење на толониумхлорид со примена на циркониумфосфат како катализатор во присуство на светлина. Реакцијата е следена спектрофотометриски и покажано е дека е од псево-прв ред. Утврден е ефектот од промена на повеќе процесни променливи, како што се концентрација на толониумхлорид, $\mathrm{pH}$, количество на фотокатализатор и интензитет на светлината врз брзината на реакција. Предложен е механизам на реакција на фотокаталитичко белење на толониумхлорид.
\end{abstract}

Клучни зборови: третман на стандардни води; фотокаталитичко белење; толониумхлорид; циркониумфосфат; полуспроводник

\section{INTRODUCTION}

As we stepped into the twenty-first century, we are facing the challenge of purification of water and air resources. On one hand, we are enjoying the comforts and benefits that chemistry has provided to us, e.g. from drugs to dyes, from composites to computer chips, etc. On the other hand, we are facing with the problem of proper disposal of various products and byproducts of dye industries. Inspite of many uses, the dyes are toxic and carcinogenic in nature and environmental contamination by these toxic chemicals is emerging as a serious global problem. Coloured solution containing dyes from industrial effluents of textile, dyeing and printing industries may cause skin cancer due to photosensitization and photodynamic damage. On the other hand, bleached dye solution is less toxic and almost harmless. Secondly, dye containing coloured water is of almost no use, but if this coloured solution is bleached to give colourless water, then it may be used for washing, cool- 
ing, irrigation and cleaning purpose. The photocatalytic bleaching seems to be quite promising and can provide a low cost method to solve this problem.

The field of photocatalysis has been excellently reviewed by Ameta et al. [1, 2]. Photocatalytic degradation of cetylpyridinium chloride over $\mathrm{TiO}_{2}$ has been reported by Singhal et al. [3]. Similar photocatalytic reaction of xylidine ponceau and orange- $\mathrm{G}$ dyes by $\mathrm{ZnO}$ powder has been reported by Sharma et al. [4]. Yoneyama et al. [5] studied the photocatalytic reduction of dichromate ions using $\mathrm{WO}_{3}$ powder in acidic range. Costa et al. [6] proposed the mechanism of gas phase degradation of cyclohexanol and methylcyclohexanol catalyzed by zirconium phosphate and phosphite. Shyama and Arakawa [7] have used zirconium dioxide as photocatalyst. A composite system of polycrystalline $\mathrm{ZnO} / \mathrm{TiO}_{2}$ and its photocatalytic activity was studied by Marci et al. [8].

$\mathrm{TiO}_{2}$ sol-gel deposited over glass and its application as a photocatalyst for water decontamination has been reported by Gelover et al. [9]. Kako et al. [10] suggested some preventive methods against catalytic poisoning of $\mathrm{TiO}_{2}$ photocatalyst by $\mathrm{H}_{2} \mathrm{~S}$. The effect of $\mathrm{TiO}_{2}$ acidic pre-treatment on the photocatalytic phenol degradation was reported by Colon et al. [11] whereas photodegradation of lignin from black liquor using a $\mathrm{UV} / \mathrm{TiO}_{2}$ system was investigated by Ksibi et al. [12]. Enhanced efficiency of unsymmetrical versus symmetrical squaraine dyes sensitized nanocrystalline $\mathrm{TiO}_{2}$ was reported by Alex et al. [13]. Morwetz and Selli [14] investigated the effect of iron species in photocatalytic degradation of azo dye in $\mathrm{TiO}_{2}$ suspension.

Kim et al. [15] used $\mathrm{ZnO}$ coated $\mathrm{TiO}_{2}$ nanoparticles for the flexible dye-sensitized solar cells. Use of semiconducting iron(II) oxide in photocatalytic bleaching of some dyes (malachite green, crystal violet and methylene blue) has been reported by Ameta et al. [16]. Photocatalytic degradation of brilliant red dye and textile waste water has been suggested by Martins et al. [17]. Photocatalytic degradation of acid blue-62 over $\mathrm{CuO}$ $\mathrm{SnO}_{2}$ nanocomposite photocatalyst under simulated sunlight has been reported by Xia et al. [18]. The photocatalytic bleaching of tolonium chloride in presence of zirconium phosphate photocatalyst is being reported in the present investigation. Bleaching of some dyes using zirconium phos- phate photocatalyst have been studied by Panwar et al. [19].

\section{EXPERIMENTAL DETAILS}

\section{Preparation of photocatalyst (zirconium phosphate)}

Zirconium phosphate was prepared by the reaction between zirconium oxychloride (LOBA, $1.610 \mathrm{~g}$ ) and disodium hydrogen phosphate (Ranbaxy, $1.595 \mathrm{~g}$ ). Zirconium oxychloride and disodium hydrogen phosphate were dissolved in distilled water separately. The disodium hydrogen phosphate solution (aqueous) was added slowly to the aqueous zirconium oxychloride solution under agitation, at room temperature. Zirconium phosphate precipitated out. To ensure complete precipitation, excess amount of disodium hydrogen phosphate solution was added to the supernatant layer. If there was no further precipitation, the solution was filtered. After several washes with water, the product was dried at room temperature under vacuum. Zirconium phosphate was used as a semiconductor (photocatalyst) in the present investigations for the degradation of tolonium chloride (Ranbaxy) dye. The reaction was observed spectrophotometrically, in which optical density (O.D.) of the solution at different time intervals was measured. The optical density was measured by placing an aliquot of $2 \mathrm{ml}$ dye solution in a cuvett and putting the cuvett in the spectrophotometer.

\section{Degradation of tolonium chloride using zirconium phosphate}

Tolonium chloride is 3-amino-7-(dimethylamino)-2-methyl-phenothiazin-5-ium chloride. It is known as tolonium blue-O or tolonium blue.<smiles>CCOC(=O)c1ccc2nc3cc(C)c(N)cc3[s+]c2c1</smiles> 
Its solution in water is blue in color. A $0.0682 \mathrm{~g}$ of tolonium chloride was dissolved in $500.0 \mathrm{ml}$ of doubly distilled water so that the concentration of the dye solution was $2.0 \times 10^{-3} \mathrm{M}$. This solution was used as stock solution. The photocatalytic degradation of tolonium chloride was observed on a $30 \mathrm{ml}$ dye solution $\left(5.00 \times 10^{-5} \mathrm{M}\right)$, which was prepared in doubly distilled water, and adding $0.10 \mathrm{~g}$ zirconium phosphate (photocatalyst). Irradiation was carried out by keeping the whole assembly exposed to a $200 \mathrm{~W}$ tungsten lamp (Philips, light intensity $=50.0 \mathrm{mWcm}^{-2}$ ). The intensity of light at various distances from the lamp was measured with the help of a Solarimeter (SM CEL 201). A water filter was used to cut out the thermal radiations. A digital pH meter (Systronics Model 106) was used to measure the $\mathrm{pH}$ of solution. The desired $\mathrm{pH}$ of solution was adjusted by the addition of previously standardized sulphuric acid and sodium hydroxide solutions. The necessary condition for the correct measurement of the optical density is that the solution must be free from semiconductor particles and impurity and therefore, a centrifuge (REMI - 1258) was used to remove these particles by centrifugation, followed by decantation of the supernatant liquid.

The progress of the reaction was monitored spectrophotometrically by measuring the optical density (O.D.) of the dye solution at various time intervals. Controlled experiments were also carried out to confirm that the reaction is neither photochemical nor thermal, but it is photocatalytic.

\section{RESULTS AND DISCUSSION}

The photocatalytic degradation of tolonium chloride was observed at $\lambda_{\max }=640 \mathrm{~nm}$. The results of a typical run are graphically represented in Fig. 1. The plot of $\log$ O.D. v/s exposure time is a straight line. This indicates that the photocatalytic degradation of tolonium chloride in presence of zirconium phosphate follows pseudo first order kinetics and the rate constant for this reaction was determined using the expression $k=2.303 \times$ slope. The first point (at $0 \mathrm{~min}$ ) in the typical run (Fig. 1) is out of the trend because initially some dye molecules will be absorbed on the surface of the photocatalyst and therefore, it was excluded from the trend observed for the whole reaction.

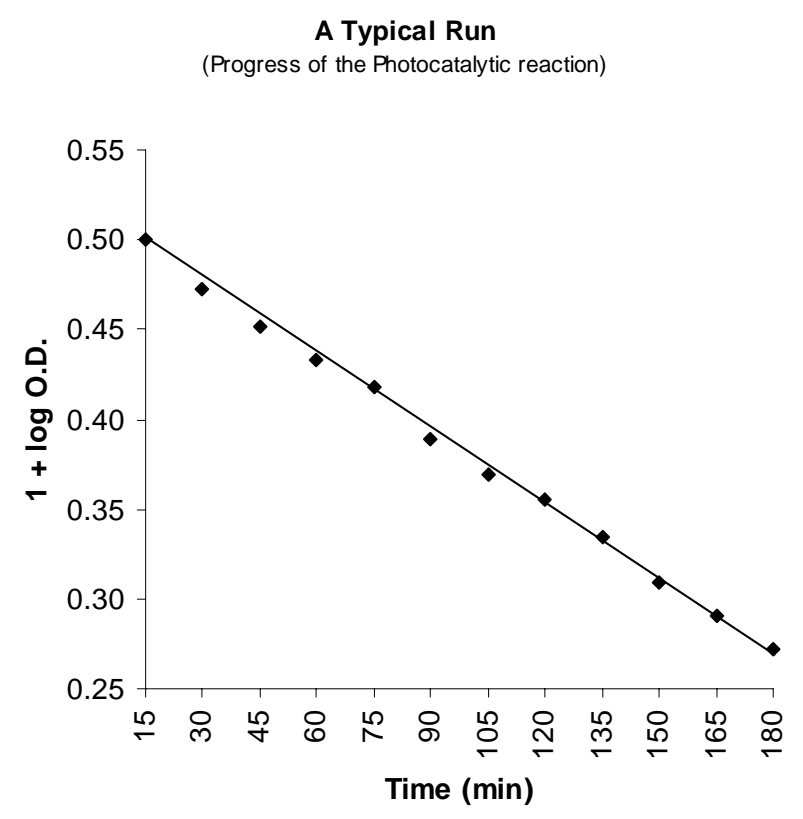

Fig. 1. Variation of dye concentration with time of exposure. Conditions: [Tolonium chloride] $=5.00 \times 10^{-5} \mathrm{M}, \mathrm{pH}=7.5$, Zirconium phosphate $=0.10 \mathrm{~g}$ and light intensity $=50.0 \mathrm{~mW} \mathrm{~cm}^{-2}$

\section{Effect of the $p H$}

The effect of $\mathrm{pH}$ on photocatalytic degradation was also investigated. The results are reported in Table 1 and are graphically presented in Fig. 2.

Table 1

Effect of $\mathrm{pH}$ on the rate of photocatalytic degradation of tolonium chloride

\begin{tabular}{cc}
$\begin{array}{c}\text { [Tolonium chloride }]=5.00 \times 10^{-5} \mathrm{M} \\
\text { Zirconium phosphate }=0.10 \mathrm{~g}\end{array}$ & $k \times 10^{5}\left(\mathrm{~s}^{-1}\right)$ \\
\hline $\mathrm{pH}$ & 4.94 \\
7.00 & 5.16 \\
7.25 & 5.24 \\
7.50 & 4.60 \\
7.75 & 4.24 \\
8.00 & 3.99 \\
8.25 & 3.72 \\
8.50 & 3.41 \\
8.75 & 3.17 \\
9.00 &
\end{tabular}




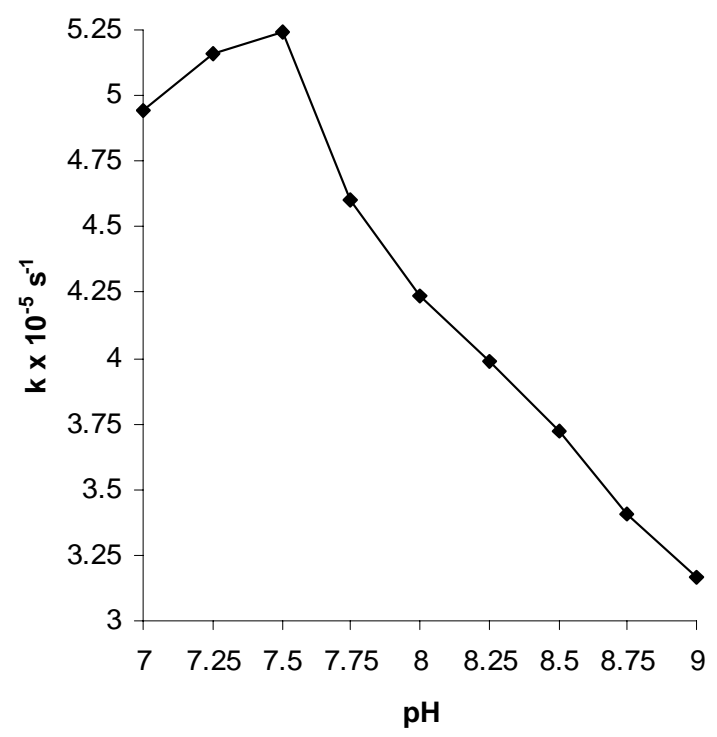

Fig.2. Effect of $\mathrm{pH}$ on the rate of photocatalytic degradation of tolonium chloride.

Conditions: [Tolonium chloride $]=5.00 \times 10^{-5} \mathrm{M}$, Zirconium phosphate $=0.10 \mathrm{~g}$ and light intensity $=50.0 \mathrm{~mW} \mathrm{~cm}^{-2}$

It was observed that with an increase in $\mathrm{pH}$, the rate of photocatalytic degradation of the dye increases from 7.00 to 7.50. On further increasing the $\mathrm{pH}$, a decrease in the rate of photocatalytic bleaching was observed. This behaviour can be explained on the basis that as the $\mathrm{pH}$ of the solution increases, more $\mathrm{OH}^{-}$ions are available. $\mathrm{OH}^{-}$ ions will generate more ${ }^{\circ} \mathrm{OH}$ radicals by combining with the hole of the semiconductor and these ${ }^{\circ} \mathrm{OH}$ are considered responsible for the photocatalytic bleaching. After a certain $\mathrm{pH}$ value, more $\mathrm{OH}^{-}$ions in the bulk will retard the approach of the dye molecules towards the semiconductor surface in the desired time limit due to the decrease in the movement of the large dye molecules. This will result in a decrease in the rate of photocatalytic bleaching of tolonium chloride. The participation of ${ }^{\bullet} \mathrm{OH}$ radicals in the reaction was confirmed by carrying out the reaction in presence of oxalate ions, which act as hole $\left(\mathrm{h}^{+}\right)$scavenger through the following reaction.

$$
\mathrm{h}^{+}+(\mathrm{COO})_{2}{ }^{-2} \longrightarrow \mathrm{CO}_{2}
$$

\section{Effect of the tolonium chloride concentration}

The effect of variation of dye concentration was also studied by taking different concentrations of tolonium chloride. The results are tabulated in Table 2 and graphically presented in Fig. 3.
Table 2

Effect of concentration of tolonium chloride on the rate of photocatalytic degradation

\begin{tabular}{|c|c|}
\hline \multicolumn{2}{|c|}{$\begin{aligned} \text { Light intensity } & =50.0 \mathrm{~mW} \mathrm{~cm}^{-2} \text { Zirconium phosphate }=0.10 \mathrm{~g} \\
\mathrm{pH} & =7.5\end{aligned}$} \\
\hline [Tolonium chloride] $\times 10^{5} \mathrm{M}$ & $k \times 10^{5}\left(\mathrm{~s}^{-1}\right)$ \\
\hline 3.00 & 4.62 \\
\hline 3.50 & 4.74 \\
\hline 4.00 & 5.05 \\
\hline 4.50 & 5.13 \\
\hline 5.00 & 5.25 \\
\hline 5.50 & 4.92 \\
\hline 6.00 & 4.64 \\
\hline 6.50 & 4.37 \\
\hline 7.00 & 4.14 \\
\hline
\end{tabular}

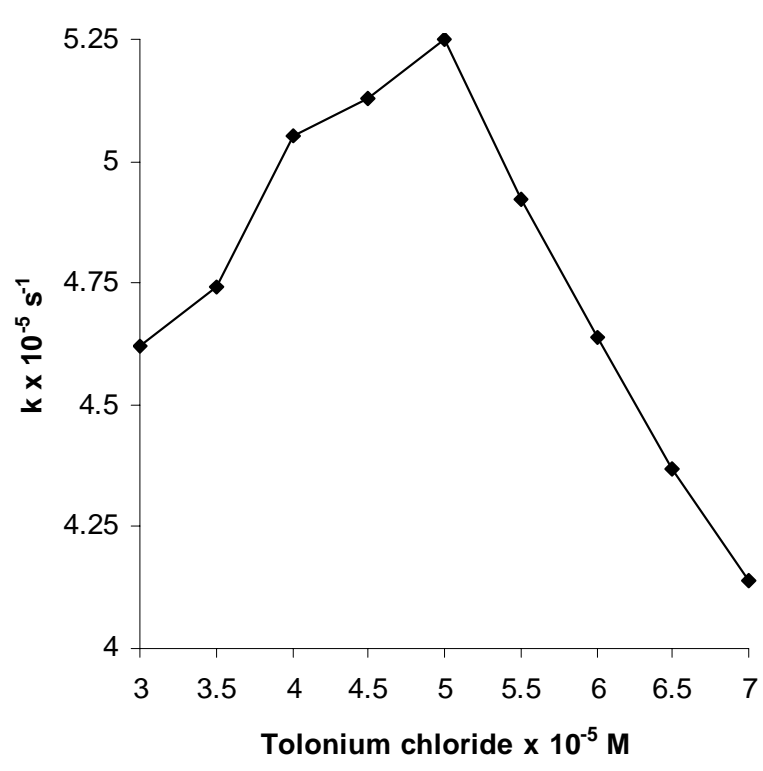

Fig. 3. Effect of concentration of tolonium chloride on the rate of photocatalytic degradation.

Conditions: Light intensity $=50.0 \mathrm{~mW} \mathrm{~cm}{ }^{-2}$,

Zirconium phosphate $=0.10 \mathrm{~g}$ and $\mathrm{pH}=7.5$

From the data presented, it is clear that the rate of photocatalytic degradation increases with increasing concentration of the dye (up to $5.0 \times 10^{-5} \mathrm{M}$ ). This may be attributed to the fact that as the concentration of tolonium chloride was increased, more dye molecules were available for excitation followed by inter system crossing and hence, there was an increase in the rate. Further increase in the concentration of the dye (i.e. above $5.00 \times 10^{-5} \mathrm{M}$ ) resulted in a decrease in the rate of reaction. This may be explained on the basis that at higher concentrations, the dye starts acting as a filter for the 
incident light and it does not permit the desired light intensity to reach the semiconducting particles and thus, the rate of the photocatalytic bleaching of tolonium chloride decreases.

\section{Effect of the amount of semiconductor}

The amount of semiconductor is also likely to affect the rate of photocatalytic degradation of tolonium chloride. Different amounts of photocatalyst (zirconium phosphate) were used and the results are summarized in Table 3 and graphically presented in Fig.4

It was observed that as the amount of semiconductor increased, the rate of photodegradation of tolonium chloride also increased, but ultimately the reaction rate become constant after a certain amount $(0.10 \mathrm{~g})$ of semiconductor. This may be due to the fact that as the amount of semiconductor was increased, the exposed surface area also increased, but after a certain limit (a point of saturation), if the amount of zirconium phosphate was further increased, there will be no increase in the exposed surface area of the photocatalyst. It may be considered like a saturation point above which any increase in the amount of semiconductor has negligible or no effect on the rate of photocatalytic bleaching of tolonium chloride because any increase in the amount of semiconductor after this saturation point will only increase the thickness of the layer at the bottom of the vessel. This behaviour was confirmed by using reaction vessels of different dimensions and taking several solutions of different dye concentrations.

Table 3

Effect of amount of semiconductor on the rate of photocatalytic degradation of tolonium chloride

\begin{tabular}{cc}
\hline \hline $\begin{array}{c}\text { [Tolonium chloride }=5.00 \times 10^{-5} \mathrm{M} \\
\text { Light intensity }=50.0 \mathrm{~mW} \mathrm{~cm}\end{array}$ & $\mathrm{pH}=7.5$ \\
\hline Zirconium Phosphate $(\mathrm{g})$ & $k \times 10^{5}\left(\mathrm{~s}^{-1}\right)$ \\
\hline 0.04 & 2.51 \\
0.05 & 3.22 \\
0.06 & 4.41 \\
0.07 & 4.57 \\
0.08 & 4.80 \\
0.09 & 5.02 \\
0.10 & 5.24 \\
0.11 & 5.23 \\
0.12 & 5.24 \\
\hline \hline
\end{tabular}

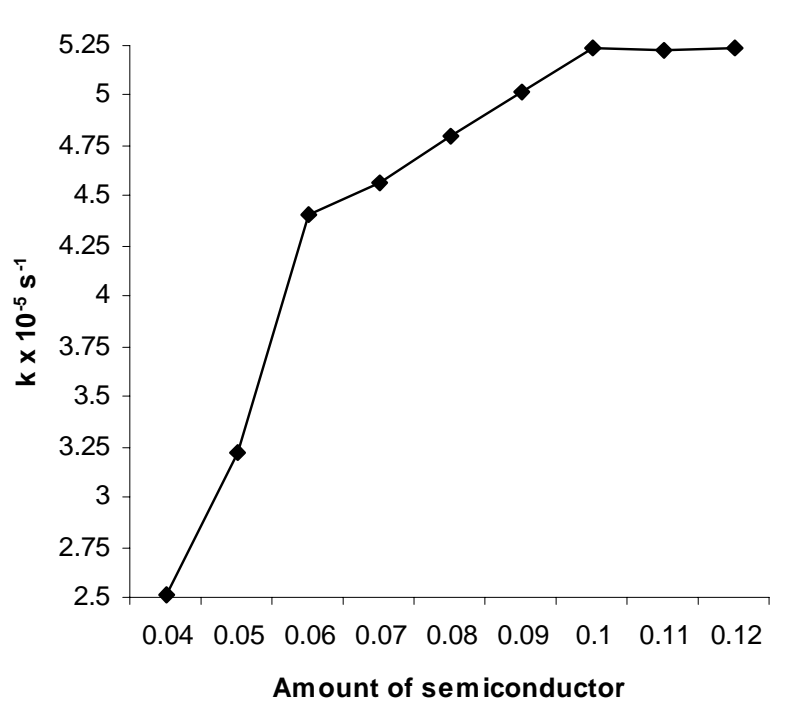

Fig. 4. Effect of amount of semiconductor on the rate of photocatalytic degradation of tolonium chloride.

Conditions: [Tolonium chloride] $=5.00 \times 10-5 \mathrm{M}, \mathrm{pH}=7.5$ and light intensity $=50.0 \mathrm{~mW} \mathrm{~cm} \mathrm{~m}^{-2}$

\section{Effect of the light intensity}

The effect of the variation of light intensity on the rate was also investigated and the observations are reported in the Table 4 and graphically presented in Fig.5

The results indicate that the bleaching action was accelerated as the intensity of light was increased, because any increase in the light intensity will increase the number of photons striking per unit area of semiconductor powder. An almost linear dependence between the light intensity and rate of reaction was observed. However, higher intensities were avoided due to thermal effects.

\section{Table 4}

\section{Effect of light Intensity on the rate of photocata- lytic degradation of tolonium chloride}

$[$ Tolonium chloride $]=5.00 \times 10-5 \mathrm{M}$ Zirconium phosphate $=0.10 \mathrm{~g}$ $\mathrm{pH}=7.5$

\begin{tabular}{cc}
\hline Intensity of light $\left(\mathrm{mW} \mathrm{cm}^{-2}\right)$ & $k \times 10^{5} \mathrm{~s}^{-1}$ \\
\hline 20.0 & 3.46 \\
30.0 & 3.96 \\
40.0 & 4.26 \\
50.0 & 4.60 \\
60.0 & 4.72 \\
70.0 & 5.21 \\
80.0 & 5.54 \\
\hline \hline
\end{tabular}




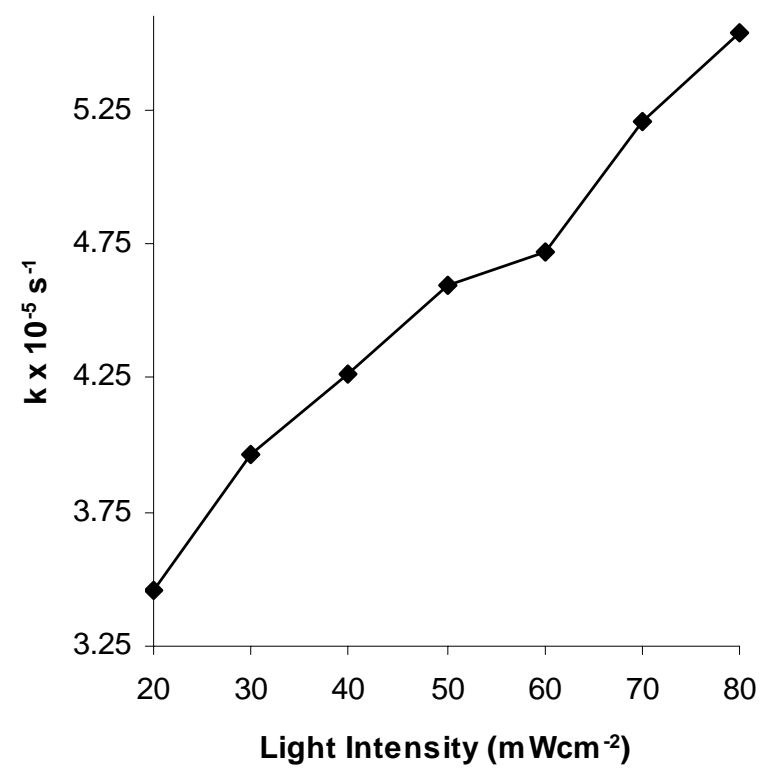

Fig. 5. Effect of light Intensity on the rate of photocatalytic degradation of tolonium chloride.

Conditions: [Tolonium chloride] $=5.00 \times 10^{-5} \mathrm{M}$, Zirconium phosphate $=0.10 \mathrm{~g}$ and $\mathrm{pH}=7.5$.

\section{MECHANISM}

On the basis of the experimental observations, a tentative mechanism for photocatalytic bleaching of tolonium chloride may be proposed as

$$
\begin{aligned}
& \text { Dye } \longrightarrow{ }^{* 1} \text { Dye } \\
& { }^{* 1} \text { Dye } \longrightarrow{ }^{* 3} \text { Dye } \\
& \mathrm{SC} \longrightarrow \mathrm{e}^{-}(\mathrm{CB})+\mathrm{h}^{+}(\mathrm{VB}) \text { or } \mathrm{SC}^{+} \\
& \mathrm{h}^{+}+\mathrm{OH}^{-} \longrightarrow \mathrm{OH}^{\bullet} \\
& { }^{* 3} \mathrm{Dye}+\mathrm{OH}^{\bullet} \longrightarrow \text { Colorless Product }
\end{aligned}
$$

The dye (tolonium chloride) absorbs radiation of suitable wavelength and it is excited to its first singlet state followed by intersystem crossing (ISC) to triplet state (Eq. 1 and 2). On the other hand, the semiconducting zirconium phosphate (SC) also utilized the incident light energy to excite its electron from valence band to conduction band (Eq. 3), thus leaving behind a hole. This hole may abstract an electron from the $\mathrm{OH}^{-}$ions to generate ${ }^{\circ} \mathrm{OH}$ radicals (Eq. 4). The excited dye may be oxidized to products by ${ }^{\circ} \mathrm{OH}$ radicals (Eq. 5). The participation of ${ }^{\bullet} \mathrm{OH}$ radicals as an active oxidizing species was confirmed using its scavenger, i.e. 2- propanol, where the rate of bleaching was drastically reduced.

\section{CONCLUSION}

The photocatalytic decolourization of tolonium chloride over zirconium phosphate provides an ecofriendly method for degradation of the dye. The photocatalytic process may be utilized for the treatment of effluents from dyes and printing industries.

The decolourization efficiency increases with increasing in $\mathrm{pH}$, attaining maximum value at $\mathrm{pH}$ 7.50 .

The photocatalytic degradation of follows pseudo first order kinetics.

The principal oxidizing species responsible for the dye decolourization is the hydroxyl radicals ('OH radical).

Acknowledgements: The authors are grateful to Head, Department of Chemistry, University College of Science, Udaipur for providing necessary laboratory facilities.

\section{REFERENCES}

[1] S. Sahasi, N. K. Jain, M. Dak, M. Bala, S. C. Ameta, Heterogeneous and homogeneous photocatalysis, part IInorganic substrates, Asian j. Chem. Rev., 2, 90-99 (1991).

[2] Z. Ali, R. Ameta, J. Vardia, R. Ameta, S. C. Ameta, Photocatalysis : A frontier of photochemistry, J. India Chem. Soc., 78, 281-287 (1999).

[3] B. Singhal, A. Porwal, A. Sharma, R. Ameta, S. C. Ameta, Photocatalytic degradation of cetylpyridinium chloride over titanium dioxide powder, J. Photochem. Photobiol. A, 108, 85-88 (1997).

[4] A. Sharma, P. Rao, R. P. Mathur, S. C. Ameta, Photocatalytic reactions of xylidin ponceau on semiconducting zinc oxide powder, J. Photchem. Photobiol. A, 86, 197200 (1995).

[5] H. Yoneyama, Y. Yamashita, H. Tamura, Heterogeneous photocatalytic reduction of dichromate on $n$-type semiconductor catalysts, Nature, 282, 817-818 (1979).

[6] M. C. C. Costa, L. F. Hodson, R. A. W. Johnstone, J. Y. Liu, The mechanism of gas-phase dehydration of cyclohexanol and the methylcylohexanols catalysed by zirconium phosphate and zirconium phosphate, J. Mol. Catl.A, 142, 349-360 (1999).

[7] K. Sayama, H. Arakawa, Photocatalytic decomposition of water and photocatalytic reduction of carbon dioxide over zirconia catalyst, J. Phys. Chem., 97, 531-533 (1993).

[8] G. Marci, V. Augughiaro, R. J. D. Tilley, M. J. LopezMunoz, C. Martin, I. L. Palmisano, V. Rives, M. S. 
Schiavello, Preparation characterization and photocatalytic activity of polycrystalline $\mathrm{ZnO} / \mathrm{TiO}_{2}$ systems. $J$. Phys. Chem. B, 105, 1026-1032 (2001).

[9] S. Gelover, P. Mondragon, A. Jimenez, Titanium dioxide sol-gel deposited over glass and its application as a photocatalyst for water decontamination, J. Photochem. Photobiol. A, 165, 241-246 (2004).

[10] T. Kako, H. Irie, K. Hashimoto, Prevention against catalytic poising by $\mathrm{H}_{2} \mathrm{~S}$ utilizing $\mathrm{TiO}_{2}$ photocatalyst, $J$. Photochem. Photobiol. A, 171, 131-135 (2005).

[11] G. Colon, J. M. Sanchez-Espana, M. C. Hidalgo, J. A. Navio, Effect of $\mathrm{TiO}_{2}$ acidic pretreatment on the Photocatalytic properties for phenol degradation, J. Photochem. Photobiol. A, 179, 20-27 (2006).

[12] M. Ksibi, S. Ben-Amor, S. Cherif, E. Elaouim A. Houas, M. Elaloui, Photodegradation of lignin from black liquor using a $\mathrm{UV} / \mathrm{TiO}_{2}$ system, J. Photochem. Photobiol. A, 154, 211-218 (2003).

[13] S. Alex, U. Santosh, D. Das, Dye sensitization of nanocrystalline $\mathrm{TiO}_{2}$ : enhanced efficiency of unsymmetrical versus symmetrical squaraine dyes, J. Photochem. Photobiol. A, 172, 63-71 (2005).
[14] M. Morwetz, E. Selli, Effect of iron species in the photocatalytic degradation of an azo dye in $\mathrm{TiO}_{2}$ aqueous suspensions, J. Photochem. Photobiol. A, 162, 89-95 (2004).

[15] S. S. Kim, J. H. Yun, Y. E. Sung, Flexible dye sensitized solar cells using $\mathrm{ZnO}$ coated $\mathrm{TiO}_{2}$ nanopraticles, J. Photochem. Photobiol. A, 171, 269-273 (2005).

[16] R. Ameta, J. Vardia, P. B. Punjabi, S. C. Ameta, Use of semiconducting iron(III) oxide in photocatalytic bleaching of some dyes, Indian J. Chem. Tech., 13, 114-118 (2006).

[17] A. F. Martins, M. L. Wilde, C. Da Silveira, Photocatalytic degradation of brilliant red dye and textile wastewater, $J$. Environ. Sci. Health. A, 41, 675-685 (2006).

[18] H. L. Xia, H. S. Zhuang, T. Zhang, D. C. Xiao, Photocatalytic degradation of acid blue 62 over $\mathrm{CuO}-\mathrm{SnO}_{2}$ nanocomposite photocatalyst under simulated sunlight, $J$. Environ. Sci. (China), 19, 1141-47 (2007).

[19] O. P. Panwar, A. Kumar, M. Paliwal, R. Ameta, S. C. Ameta, Use of zirconium phosphate as photocatalyst in photobleaching of some dyes, Bull. Cat. Soc. India, 7, 105-110 (2008). 